ment, Harwell) on the possibility of protection, by chemical means, from whole-body irradiation. G. Hevesy (Stockholm) described some applications of tracers to the study of radio-lesions, and A. Forssberg (Stockholm) followed with a tracer study of the problem of protection from X-radiation. E. Lorenz (Bethesda, United States) presented a hæmatological study of the recovery of guinea pigs following chronic exposure to $\gamma$-radiation. The session closed with some further consideration of the problem of protection by L. F. Nims (Upton, United States).

A. G. MADDOCK

\section{SOUTH AFRICAN ASSOCIATION FOR THE ADVANCEMENT OF SCIENCE}

\section{ANNUAL CONGRESS}

S part of the diamond jubilee celebrations of
the foundation of Salisbury, Southern Rhodesia,
the congress of the South African Association
for the Advancement of Science was held there,
during July 3-7, in conjunction with the Rhodesia
Scientific Association. The meeting was most
successful, and was attended by more than one hun-
dred visitors from the Union as well as by men of
science from both the Rhodesias. The Sociedade de
Estudos, Mozambique, was also represented. Visitors
were well entertained by the town of Salisbury, by
the Grovernor and by the Rhodesia Scientific Associa-
tion, and a number of excursions were arranged
covering most of the varied interests of those present
at the congress.

In his presidential address to the Association, Prof. C. van Riet Lowe, director of the Union Archæological Survey, spoke on "Prehistory and the Humanities", making a plea for the wider teaching and study of prehistory as a means for emphasizing the essential unity of mankind and inducing a better appreciation of spiritual values.

The sectional address to Section A of the Association, by Mr. W. J. Jarvis, dealt with "Planning from a Multi-Racial Aspect" and considered some of the problems involved in integrating the native population into an introduced Western way of life. To Section B, Dr. A. M. Macgregor spoke on "The Primary Source of Gold", suggesting that gold mineralization is related to the intrusion of granitic material into basaltic rocks from which traces of gold are dissolved and concentrated. Dr. E. R. Roux spoke to Section C on "Interspecific Plant Hybrids" and cited examples of hybridization between apparently different genera which closer investigation shows might be merely very different adaptations; more studies on hybrids are needed. The address to Section D dealt with "Aspects of Museum Research", in which Mr. Reay H. N. Smithers, director of the National Museum, Bulawayo, showed the value of taxonomic studies in museums and urged the need for expansion of these services, which are basic to other biological researches. To Section E, Mr. Roger Summers, also of the National Museum, described "Iron Age Cultures in Southern Rhodesia", dealing particularly with the many ancient ruins and proposing a tentative chronology for them and for the Iron Age pottery found in the country.
Following the suggestion made by the United Nations Educational, Scientific and Cultural Organisation, a symposium was held on the theme of "Man's Use of Energy". An outstanding contribution was the first authoritative account of the plan to dam the waters of the Zambesi River at the Kareba Gorge, some two hundred miles below the Victoria Falls, and to set up power plants to develop about one million kVA. The dam would also make possible a big irrigation project.

Particular interest was aroused in the popular evening lecture-always a feature of the yearly congress-which this year was given by Dr. S. H. Skaife, of Cape Town, and included a colour film showing the activities of termites which he has kept for fifteen years in specially designed and constructed nests. The life-cycle of the insects was traced, and many new sidelights thrown on the totalitarian regime of these creatures, which were seen on the screen at very large magnifications.

\section{THE NATURALIST IN THE FIELD TO-DAY}

$\mathrm{T}$

HE Nature Conservancy is now in being and is a potential check against the destruction of areas in Great Britain of special importance from the point of view of geological structure, vegetation or other wild life, or of scenic beauty. The widespread seizure of these areas for afforestation, agriculture, Service requirements, etc., makes it all the more imperative to preserve what is left. But reserves can never be administered effectively by remote committees-still less from a 'window in Whitehall'. The care and vigilance of local interests, and especially of local naturalists, is needed: How far are they competent to shoulder this responsibility? This question formed the subject of the presidential address by Dr. E. A. R. Ennion to the Conference of Delegates of Corresponding Societies at the recent meeting at Birmingham of the British Association.

Dr. Ennion, as warden of Flatford Mill Field Centre, has devoted the past five years to devising ways and means whereby the 'amateur naturalist', irrespective of age, sex, background or calling, can gain increasing competence in his or her special interests. The experimental stage is almost ended.

There has been a steady rise, growing steeper in post-war years, in the 'curve of opportunity' open to the amateur naturalist. Dr. Ennion discussed some of the contributory factors in turn: books and journals ; natural history society reports ; lectures, with the improved technique now offered by various visual aids ; films; broadcasts. But all these have one fundamental weakness-the recording of someone else's triumphs and experiences. Only by personal exertions and discoveries is anyone really able to become a naturalist.

The opportunities for first-hand experience and guidance in field-work have increased considerably, although mainly for two groups: the university student, who has facilities especially for marine work at Plymouth, Millport, Port Erin, etc.; and the ornithologist, at any of the small coastal bird observatories, Skokholm, Lundy, Spurn Head, etc. A trend towards establishing inland stations is growing, too: Oxford at Wytham; Cambridge at Madingley ; and the narrow boat Beatrice of the Severn Wildfow] Trust are instances in point. 
Much still remains to be done in at least three directions: (a) provision for field-work other than marine (or freshwater) biology and ornithology ; (b) ensuring effective linkages between the various branches; and (c) provision for the guidance and reception of the individual inexpert but potentially serious student.

Flatford Mill, where Dr. Ennion took his first students in May 1946, and the three other centres of the Council for the Promotion of Field Studies-Dale Fort, Juniper Hall and Malham Tarn-go part of the way towards filling these deficiencies. Each accepts between forty and fifty students a week from March to October (and a few in the winter) from universities, training colleges and schools all over Britain, together with a "fair leavening of independent naturalists and artists". Each is staffed by a warden and his assistant, who cover all branches between them, the warden also being responsible for the entire organisation of his centre-an exacting post but a very much alive and worthwhile one.

A thousand university students and five hundred older independent visitors come to these field centres in the course of the year, which leaves about four thousand vacancies, distributed between the four centres, for teachers, training-college students and sixth-form boys and girls, whose previous experience of field-work is very limited. Almost all of them need the full-time co-operation of the warden and his assistant. So there is very little chance of adequate help for the occasional student- "the one in every twenty-five or so who takes to field-work like a duck to water"- -who would obviously respond keenly to individual attention.

But these occasional individuals are of prime importance : they are the amateur naturalists of the future. Dr. Ennion is leaving his post at Flatford Mill to establish a new station, the Farne Naturalists Trust, where it will be possible to welcome these students individually. Monks' House, south of Bamburgh and opposite the Farne Islands on the Northumberland coast, has been secured for this purpose. It is designed expressly for the amateur naturalist, more particularly perhaps for the ornithologist, although workers in many other branches will find ample opportunity and a ready welcome. Monks' House opens next Easter, and details will be available shortly for those who are interested in this new development.

\section{NEW ZEALAND EARTHQUAKES DURING 1947-48 AND JULY- DECEMBER 1949}

$\mathrm{R}$

C. HAYES has examined and catalogued all . earthquakes in New Zealand during $1947^{1}$ and also $1948^{2}$. In 1947 the earthquakes of Jun $\Theta 16$, from lat. $38.4^{\circ}$ S., long. $178.4^{\circ}$ E., and of October 13, lat. $44 \cdot 2^{\circ}$ S., long. $169 \cdot 0^{\circ}$ E., attained intensity 7 on the Modified Mercalli scale, and six earthquakes attained intensity 6 . The sea area between the two islands and its environs, and North Island east and northeast of the River Wanganui, had the majority of the epicentres. There were concentrations of epicentres to seaward off Gisborne, and in the Southern Alps west of Christchurch and north-east of Mount Aspiring; also a small group to seaward in the extreme south off Puysegur Point. Otherwise,
September 16, 1950 Vol. 166 throughout the year, there were very few earthquakes elsewhere.

In 1948, 127 earthquakes were reported as felt during the year. The largest disturbance occurred on May 23 in the Hanmer-Waiau region, when intensity 8 on the Modified Mercalli scale was reached. Some buildings in the epicentral region suffered structural damage, and minor activity continued at intervals for some months. Other strong shocks occurred on January 15 off the Manawatu coast, on June 19 off the west coast of the South Island, and in July in the Monowai region; the first two of these were widely felt.

Provisional seismological bulletins for July-December 1949 have been received from the Dominion Observatory, Wellington. They include readings from nine observatories, including Suva, Fiji, and a new station, Cobb, established on July 20,1949 , in lat. $41^{\circ} 5^{\prime} \mathrm{S}$., long. $172^{\circ} 44^{\prime} \mathrm{E}$., and equipped with a Wood-Anderson short-period seismograph east-west component. During the period 114 strong distant earthquakes were recorded, and 129 local shocks felt. Of shocks with instrumental magnitude 5 or greater which were felt, three were experienced in Opotiki, three in Tolaga Bay, one each in Wairoa and New Plymouth and several in Wellington.

${ }^{1}$ New Zealand Seismological Observatory Bulletin S-90 (1949). ${ }^{2}$ ibid., $R$-34 (1949).

\section{STANDARDS FOR TELEVISION SYSTEMS}

NE of the study groups of the International Consultative Committee on Radiocommunication (C.C.I.R.) has recently been exploring the possibility of obtaining international agreement on the standardization of some of the various technical factors which define the characteristics of a television system. A preliminary meeting was held at Zurich in July 1949, at which it was decided that, before meeting again in London in 1950, the study group should inspect the practice and present state of development of the existing television services in America and Europe (see Nature, 164, 477; 1949).

This inspection was carried out by representatives of some sixteen national administrations and operating organisations, and started with a visit to the United States in March and April of this year. The programme comprised a series of visits in New York, Philadelphia and Washington, D.C., for the purpose of witnessing the present-day operation of the television services available in the eastern portion of the United States, the development and production of various types of television equipment, and par. ticularly of observing demonstrations specially arranged to assist the study group in its work on standards for television. This was followed by visits to Paris and Eindhoven, where the arrangements and demonstrations were organised by the Radiodiffusion et Télévision Françaises and the N. V. Philips Gloeilampenfabrieken, respectively. Finally, in Great Britain the delegates visited various stations and establishments of the British Broadcasting Corporation and the General Post Office, and industrial laboratories and factories. In all cases, the visits and demonstrations were designed to show the present state. of television development and the different aspects of the varied and detailed work which is necessary for the establishment and maintenance of a public television service. 